\title{
Evaluasi Pelaksanaan Pos Pembinaan Terpadu (Posbindu) PTM di Kabupaten Pesisir Barat
}

\section{Analysis of The Effectiveness of Posbindu in Control and Prevention of Communicable Diseases}

\author{
Nova Susilawati*, Atikah Adyas, Achmad Djamil \\ Prodi Magister Kesehatan Masyarakat, Universitas Mitra Indonesia \\ (*novasusilawati67@yahoo.com)
}

\begin{abstract}
ABSTRAK
Tujuan penelitian yaitu mengetahui efektivititas posbindu dalam pengendalian dan pencegahan penyakit tidak menular di Kabupaten Pesisir Barat. Penelitian kualitatif pendekatan fenomenologi dan didukung data kuantitatif kasus PTM unutuk menilai effect Posbindu dalam pengendalian dan pencegahan PTM. Informan dalam penelitian ini berjumlah 19 informan terdiri dari Petugas Posbindu Puskesmas sebanyak 5 informan, kader posbindu berjumlah 4 informan dan peserta posbindu berjumlah 5 orang dan 5 informan Pembina Posbindu Puskemas dipilih menjadi triagulasi dalam penelitian ini. Hasil penelitian terhadap efektivitas posbindu di kabupaten pesisir barat masih ditemukannya masalah pada input meliputi; sumberdaya, sarana prasarana, pendanaan, proses dan output sehingga pelaksanaan Posbindu di Kabupaten Pesisir Barat belum efektif dan berdampak pada tidak terkendalinya kasus hipertensi dibuktikan dengan capaian pemeriksaan penderita hipertensi sebesar 7,76\% dan hasil pemeriksaan tekanan darah menunjukkan 429 penderita hipertensi berada pada rentang kategori buruk. Pelaksanaan Posbindu belum Efektiv dalam pengendalian dan pencegahan penyakit tidak menular di Kabupaten Pesisir Barat
\end{abstract}

Kata kunci : Posbindu, Penyakit Tidak Menular, Hipertensi

\section{ABSTRACT}

The purpose of the study was to determine the effectiveness of posyandu in controlling and preventing non-communicable diseases in Pesisir Barat Regency. Qualitative research with a phenomenological approach and supported by quantitative data on cases of non-communicable diseases to assess the effect of Posbindu in the control and prevention of non-communicable diseases. The informants in this study were 19 informants consisting of 5 Posbindu health officers, 4 posbindu cadres and 5 posbindu participants and 5 Posbindu Advisory informants were selected as triagulation in this study. The finding of problems in inputs include: resources, infrastructure, funding, processes and outputs so that the implementation of Posbindu in Pesisir Barat Regency has not been effective and has an impact on uncontrolled hypertension cases as evidenced by the achievement of examination of hypertension patients by $7.76 \%$ and the results of blood pressure examinations showing 429 Patients with hypertension are in the poor category range. The implementation of Posbindu has not been effective in controlling and preventing non-communicable diseases in Pesisir Barat Regency

Keywords : Posbindu, Non-Communicable, Hypertension

https://doi.org/10.33860/jik.v15i2.494

(C) 2021 by the authors. Submitted for possible open access publication under the terms and conditions of the Creative

Commons Attribution (CC BY SA) license (https://creativecommons.org/licenses/by-sa/4.0/). 


\section{PENDAHULUAN}

Sebagaimana diketahui bahwa penyakit wabah covid-19 telah melanda dunia sejak tahun 2019 sampai saat ini. Beberapa negara menyatakan bahwasanya PTM menjadi faktor penyerta (Komorbid) yang memperburuk kondisi penderita covid-19[1]. PTM merupakan jenis penyakit yang pada tahap perkembangannya membutuhkan jangka waktu yang lama atau menahun (kronis)[2]. Menurut World Health Organization (2018) PTM telah membunuh 41 juta orang pertahunnya atau sekitar $71 \%$ penyebab kematian didunia. Dari semua jenis PTM penyebab kematian didunia mayoritas disebabkan oleh Penyakit jantung dan pembuluh darah sebesar 17,9 juta orang kemudian disusul dengan penyakit kanker sebesar 90 juta orang, 3,9 juta orang dikarenakan penyakit pernafasan, 1,6 juta orang dikarenakan penyakit diabetes melitus dan diprediksi akan ada peningkatan sebesar 52 juta jiwa kematian pada tahun 2030, naik 9 juta jiwa dari 38 juta jiwa pada saat ini. Indonesia mengalami peningkatan beban akibat PTM. Data ini tidak jauh berbeda dengan kasus PTM di Indonesia. Data riset menunjukan kenaikan prevalensi kasus penyakit kanker $0,4 \%$, stroke $3,9 \%$, gagal ginjal kronik $1,8 \%$, diabetes melitus 1,6\% dan hipertensi 8,3. Sedangkan untuk Provinsi Lampung, prevalensi PTM juga mengalami peningkatan seperti diabetes melitus $0,2 \%$, dan hipertensi 5,24\% [3,4]. Meningkatnya frekuensi kejadian PTM menjadikan PTM sebagai target dalam Sustainable Development Goal (SDGs) 2030 yakni mengurangi hingga $1 / 3$ kematian dini dikarenakan PTM.

Posbindu merupakan upaya kesehatan berbasis masyarakat guna menerapkan upaya pendeteksidinian dan pemantauan faktor resiko PTM. Posbindu adalah kegiatan pendeteksian dini, kegiatan memonitoring serta menindaklanjuti faktor risiko secara dini, mandiri, berkesinambungan dibawah pembinaan puskesmas dengan sasaran utama adalah masyarakat berusia $\geq 15$ tahun kategori sehat, memiliki faktor risiko serta penyandang melalui penguatan promosi, preventif yang dilaksanakan terintegrasi, berkelanjutan dan konsisten [5]. Dalam upaya pengendalian dan pencegahan PTM, Pemerintah Kabupaten Pesisir Barat memiliki 59 posbindu yang berada dibawah binaan 8 Fasilitas Kesehatan dari 11 Faskes tingkat pertama dengan total keseluruhan desa di Kabupaten Pesisir Barat sebanyak 118 kelurahan [6,7,8]. Berdasarkan data dan informasi dari profil dinas Kesehatan Kabupaten Pesisir Barat terkait frekuensi kasus hipertensi di Puskesmas se-kabupaten Pesisir Barat sebagai salah satu penyakit tidak menular cenderung meningkat dari 4,2\% (2014) menjadi $5,6 \%$ pada tahun 2015. Sedangkan pada tahun 2018 sebanyak 751 kasus dan mengalami penurunan dimasa pandemic covid-19 yakni 392 kasus pada tahun 2019. Hal ini tidak jauh berbeda dengan kasus diabetes melitus dari 265 kasus (2018) menjadi 164 kasus dimasa pandemic covid-19 (2019).

Hasil rekapitulasi laporan pemegang Program Pengendalian dan Pencegahan PTM Dinas Kesehatan Pesisir Barat tahun 2019 menunjukan bahwa kunjungan Posbindu masih dibawah sasaran target dinas Kesehatan Kabupaten Pesisir Barat yakni $\pm 15,210$ kunjungan dari $\pm 97,614$ target sasaran. Terhitung bulan januari s/d oktober 2020, pada masa pandemik covid-19 mengalami penurunan sebesar \pm 5988 kunjungan posbindu dari target sasaran sebelum pandemic yakni sebesar $\pm 95,803$ kunjungan. Berdasarkan rekapitulasi Kunjungan Posbindu pada bulan Februari tahun 2021 pada Puskesmas diwilayah kerja Kab. Pesisir Barat sebanyak 50 penyandang PTM didapatkan data bahwa 17 orang penderita Hipertensi berada pada pengukuran tekanan darah $\geq 140 / 90 \mathrm{mmHg}, 15$ penderita Diabetes melitus berada pada pengukuran kadar gula darah $>200 \mathrm{mg} / \mathrm{dL}, 8$ penderita mengalami kenaikan pengukuran IMT $>25 \mathrm{~kg} / \mathrm{m}^{2}$, dan 10 penderita kolesterol berada pada hasil pengukuran $\geq 190 \mathrm{mg} / \mathrm{dL}$. Data diatas menunjukan bahwa pengendalian dan pencegahan PTM pada penyandang PTM di Kabupaten Pesisir Barat belumlah sesuai harapan target sasaran yakni 100\% dan PMK No.5 tahun 2017 yakni hipertensi sebesar $23,4 \%$, obesitas sebesar $15,4 \%$, gula darah sebesar 6,27\%. Ketidakterkendalinya PTM terutama dimasa pandemic covid-19 akan berdampak pada peningkatan morbiditas, mortalitas dan disabiltas di Kabupaten Pesisir Barat. Studi literature yang dilakukan Mahdur menyatakan keberhasilan pelaksanaan posbindu dalam pengendalian dan pencegahan PTM perlu didukung oleh SDM yang terlatih, pendanaan yang cukup, sarana prasarana yang memadai serta partisipatif masyarakat [9]. Pernyataan ini kemudian dipertegas oleh Annisa dan Damayanti menyatakan 
pengendalian dan pencegahan PTM di Posbindu akan optimal dengan syarat memaksimalkan pemberdayaan masyarakat, kelengkapan sarana dan prasarana serta pendanaan yang cukup $[10,11]$.

Tujuan penelitian yaitu mengetahui efektivititas posbindu dalam pengendalian dan pencegahan penyakit tidak menular di Kabupaten Pesisir Barat.

\section{METODE PENELITIAN}

Jenis penelitian ini adalah penelitian kualitatif dengan pendekatan fenomenologi didukung dengan data kuantitatif kasus PTM untuk menilai effect Posbindu dalam pengendalian dan pencegahan PTM. Penelitian dilaksanakan pada tanggal 10 juni s/d 20 juli 2021 sebelum pemberlakuan pembatasan Kegiatan Masyarakat (PPKM) dan beralokasi diwilayah Kabupaten Pesisir Barat.

Subjek penelitian ini berjumlah 5 Posbindu dari 59 Posbindu dengan kriteria adalah posbindu aktif yakni kegiatan Posbindu dilaksanakan setiap bulan serta periodik. Pada setiap Posbindu ini, akan dipilih informan dan pengumpulan data pendukung berupa catatan laporan kegiatan pelaksanaan Posbindu pada bulan januari tahunan kegiatan pelaksanaan Posbindu di 5 Pusat Kesehatan Masyarakat di wilayah kerja Dinas Kesehatan Kabupaten Pesisir Barat terdiri dari: Puskesmas Lemong, Puskesmas Krui, Puskesmas Pulau Pisang, Puskesmas Krui Selatan dan Puskesmas Biha. Dari setiap Posbindu dipilih 3 informan terdiri dari: petugas Posbindu Puskesmas, kader Posbindu dan peserta Posbindu masing-masing 1 orang sehingga berjumlah 15 informan. Untuk triangulasi akan dipilih petugas pembina posbindu masing-masing 1 orang sehingga berjumlah 5 orang. Pemilihan informan peserta Posbindu PTM menggunakan kriteria inklusi yaitu berusia 15-59 tahun, rutin ke Posbindu, Penderita hipertensi, bertempat tinggal diwilayah Kabupaten Pesisir Barat dan bersedia menjadi responden. Sedangkan kriteria ekslusi yaitu menolak untuk dijadikan responden.

Instrumen pengumpulan data yang digunakan dalam penelitian ini adalah panduan wawancara (Guidea interview) dibantu dengan alat perekam suara, buku catatan, pena dan handphone berkamera untuk mendokumentasikan kegiatan penelitian. Untuk observasi data sekunder di 5 Posbindu maka peneliti menggunakan daftar checklis dengan membandingkan hasil data yang diperoleh dengan pedoman penyelenggaraan Posbindu meliputi: ketersediaan pedoman penyelenggaraan Posbindu di Puskesmas dan kader; ketersediaan dan kelengkapan posbindu kit; ketersediaan dan kelengkapan laporan kegiatan Posbindu bulan januri-juni tahun 2021; dan data jumlah kasus hipertensi di Posbindu pada bulan januari-juni tahun 2021.

Penelitian ini dinyatakan laik etik oleh komisi etik penelitian Universitas Mitra Indonesia (No. S.24/002/FKES10/2021)

\section{HASIL}

1) Sumberdaya

Penanggung jawab kegiatan posbindu terdiri dari satu orang pembina posbindu puskesmas, dua orang petugas kesehatan pelaksana posbindu sedangkan jumlah kader belum memenuhi jumlah standar minimal sesuai pedoman penyelenggaraan pelaksanaan Posbindu serta belum dilakukannya pelatihan terhadap tenaga kesehatan dan kader. Hal ini menunjukan bahwa tenaga dalam pelaksana Posbindu masih belum mencukupi sehingga berdampak pada hasil yang tidak maksimal seperti yang dipaparkan informan berikut ini:

"Untuk tenaga puskesmas dari puskesmas hanya ada dua yakni saya dan mas angga, dan kami belum dilatih (Informan A-5)

"Untuk kader biasanya ada yang empat dan ada yang sampai lima tergantung anggarannya kan mereka di gaji dari dana desa sehingga penggajian mereka berdasarkan wilayah kerjanya kalo wilayah kerjanya sedikit mbak maka sedikit jumlah kadernya kalo banyak yah banyak pula kadernya mbak. Untuk di kecamatan kami saat ini jumlah kader ada empat orang mbak sedangkan petugasnya yang berangkat ada 3 orang mbak . ada penanggung jawab posbindu, penanggung jawab posyandu lansia, penanggung jawab kesehatan jiwa dan kadang bidan pekonnya juga ikut hadir " (Informan A-4)

"Menurut saya untuk nakesnya cukup dicukupin lah mbak cuman memang selama kita bertugas turun lapangan belum pernah keteteran sih. Karena yang turun berbarengan dengan penanggung jawab lansia, keswa, ptm dan kemudian pelaksana sekitar empat orang mbak. Tapi kita belum ada yang terlatih nakesnya mbak apalagi kadernya. Yah belum ada pelatihan Posbindu PTM untuk tenaga kesehatannya, yah maunya adalah biar kita juga lebih paham tugas kita" (Informan A-2) 


\section{2) Sarana prasarana}

Setiap puskesmas di wilayah kerja Kabupaten Pesisir Barat sudah memiliki posbindu kit serta beberapa desa (pekon) juga telah menyediakan fasilitas alat pemeriksaan posbindu standar minimal yaitu alat pengukur tinggi badan, timbangan, pengukur lingkar perut, alat pemeriksaan kadar gula darah dan kolesterol. Tetapi pelaksanaan Posbindu tidak berjalan maksimal dikarenakan minimnya ketersedian bahan habis pakai seperti stick pemeriksaan kolesterol, gula dan asam urat. Guna menjamin keakuratan hasil pengukuran, alat yang digunakan di posbindu rutin dilakukan kalibrasi setiap setahun sekali oleh pihak dinas kesehatan namun jika alat telah rusak sedangkan belum ada jadwal pelaksanaan kalibrasi dari dinkes maka pihak puskesmas akan terlebih dahulu melakukan penggantian alat yang rusak guna tercapainya capaian. Hal ini sesuai dengan hasil wawancara informan berikut ini:

"Kita kan ada sebelas puskesmas jadi setiap puskesmas satu posbindu kit. Iya satu puskesmas satu, Posbindu kitnya ada dirumah tidak saya bawa ke puskesmas takut hilang (Informan D-4)"

"Iya hanya ada satu posbindu kit dengan tiga belas posbindu dan enam pedukuhan. 13 pekon itukan berarti ada enam pekon yang memiliki pedukuhan. Kemarin sih sudah saya omongin ke dinas kesehatan kan kayak kurangnya alat posbindu kit, keterbatasan alatnya yang kalo kita beli gak sesuai kemarin sudah diomongin keluhan-keluhannya yah gak tercover gitu jadi pihak dinas kesehatan memberi solusi yakni nanti kita anggarkan kembali seperti itu...." (Informan D-1).

"Ada satu buah posbindu kit, Iya ada beberapa terutama mereka itu mengeluhkan itu ketidak tersediannya alat cek stik pemeriksaan penunjang seperti kolesterolnya karena memang yang dikasih dinas itu hanya beberapa gak cukup yakni dua vial, jadi kalo tidak ada alat orang kita tidak lakukan pemeriksaan mbak (Informan D-2)"

Untuk kalibrasi alat itu dilakukan setahun sekali oleh dinas kesehatan jadi kita sering mengirimkan alat-alat untuk dikalibrasi yang kita pakai (Informan A-4)

Dalam penyelenggaraan kegiatan Posbindu setiap puskesmas sudah memiliki panduan jukni penyelenggaraan posbindu namun pendistribusian buku pintar kader kepada kader belum maksimal serta peserta posbindu belum memiliki KMS (Kartu Menuju Sehat) faktor resiko. Hal ini sesuai dengan hasil wawancara informan sebagai berikut ini:

"Tidak ada kartu itu, yang ada cuman kartu bpjs yang disuruh bawa ke posbindu, kalo yang dari petugas untuk dibawa pulang ibu gak $a d a$ " (Informan C-3)

"Enggak ada (tidak tersedia KMS), dari aku kayak membuat form pendaftaran gitu mbak jadi diusahain tiap peserta bawa ktp sama bpjs jadi itukan di catat kan di form pendaftaran kayak gitu trus setelahnya kader nyatat yang kertas itu aku ambil aku bawa pulang" (Informan D-4)

3) Pendanaan

Sumber biaya operasional dalam pelaksanaan program posbindu berasal dari BOK (biaya operasional kesehatan) dan JKN (jaminan kesehatan nasional), hanya sebagian kecamatan yang memanfaatkan dana desanya. Biaya operasional kesehatan (BOK) puskesmas hanya untuk penyediaan bahan habis pakai, biaya kerusakan pergantian alat dan biaya untuk pengganti biaya trasnport tenaga kesehatan puskesmas. Sedangkan untuk biaya mendukung pencegahan PTM (Penyakit Tidak Menular) seperti untuk mengadakan obat-obatan, strip/ stick dan peralatan posbindu kit bersumber dari dana JKN.

"Untuk pendanaan kita berfokus pada BOK, untuk obat-obatan apabila kita tidak mendapatkan dari dinas kesehatan kita dapat mengajukan dari JKN" Sebenarnya sih dibilang cukup yah Ya bisa sih sebenarnya, ya kembali lagi karena fasilitas itu tadi untuk pendanaan mungkin hanya BOK saja pembelian obat-obat dasar yang belum lengkap kalo yang lain-lainnya kita fokus pada pembagian dari dinas kesehatan" (InformanA5).

"Enggak ini kan dari dinkes, terus kalo alatalat ini kan ada dari dinkes kayak posbindu kit pokoknya itu semua dari dinas kesehatan tapi kalo ini ini (biaya transportasi petugas, penyuluhan) kan dari puskes yang ngeluarin semua itu kita cuman yang jalankan tapi kalo kita hendak ngadain penyuluhan atau apa kita yang ngeluarin dana mbak" (Informan- D3).

"Dana pekon jalan, kita minta kalo untuk tahun ini nih tahun 2021 nanti apa ada apd lagi untuk 2022 kita bilang kita udah ngomong kalo kita perlu kayak ini nya perlu apa, apa-apa ajah yang rusak maksudnya kita udah 
ngomong datain sendiri termasuk alat tulisnya permohonan posbindu mohon apa ajah gitu ke peraatin pekonnya jadi pakai dana desa, sama sekali pesertanya gak ada dipungut biaya mbak" (Informan B-2).

\section{4) Partisipatif masyarakat}

Peserta Posbindu yang rutin melakukan pemeriksaan di Posbindu mayoritas para lansia sedangkan pada usia dewasa dan remaja kurang memiliki motivasi untuk memanfaatkan posbindu, seperti yang disampaikan oleh informan berikut ini:

"Ngumpulin warganya mbak yang susah, padahal kan Posbindu itukan dari 15 tahun sampai lansia tahun tapi yang datang rata-rata lansia saja kalo anak usia dari lima belas tahun remaja-remaja yang agak susah" (Informan D-2)

"Pasien posbindu ini sedikit kebanyakan lansia, pernah dulu kakak itu ke sekolahsekolah tapi kata mereka gak usah ke sekolahsekolah diadakan posbindu di pekon-pekon ajah jadi diadakan pengumuman disuruh mereka datang kesini tapi nyatanyakan ada satu ada dua habis tu enggak ada" (Informan D-3)

"Masyarakat ini tidak terlalu berminat untuk usia tiga puluh lima tahun kebawah bukan tiga puluh lima tahun keatas mereka seperti masih males karena kita kan sudah kejar kan sudah digratisin semuanya tapi tetap tidak mau hadir" (Informan D-5)

5) Pelaksanaan Posbindu

Pelaksanaan Posbindu PTM telah berjalan sesuai dengan agenda yang dijadwalkan dan rutin setiap satu bulan sekali per pekon (desa). Pelaksanaan kegiatan umunya dilakukan di balai pekon (balai desa) masing-masing. Pelaksanaan Posbindu berintegrasi dengan kegiatan posyandu lansia, puskesmas keliling dan kesehatan jiwa dikarenakan kesulitan dalam mengumpulkan masyarakat. Posbindu diwilayah kerja Kabupaten Pesisir Barat menunjukan bahwa pelayanan diberikan oleh kader dan tenaga kesehatan. Kader umumnya hanya mengerjakan kegiatan dasar yakni pendaftaran, pengukuran tinggi badan, mengukur berat badan dan lingkar perut. Sedangkan tenaga kesehatan bertugas melakukan pemeriksaan tekanan darah, pemeriksaan laboratorium sederhana, melakukan wawancara faktor risiko ptm, konseling dan perujukan. Pelaksanaan
Posbindu belum menerapkan sistem 5 tahap serta wawancara faktor resiko PTM tidak dilakukan. Hal ini sesuai dengan hasil wawancara informan sebagai berikut:

"Oh iya mbak, itu cuman empat meja mbak belum sampai meja lima. Meja pertama pendaftaran dikerjakan oleh kader; meja kedua pengukuran tinggi badan, menimbang berat badan, dan mengukur lingkar perut dilakukan oleh kader; meja ketiga pemeriksaan tekanan darah dan cek-cek kolesterol serta pengobatan dan untuk meja ke empat pembukuan" (Informan B-4)

"Kami sampai meja ke empat ajah mbak, sampai berobat udah pulang. Awalnya ibu datang langsung di daftarkan oleh kader di meja satu diluar, terus meja dua ada didalam balai ibu diperiksa tinggi badan, menimbang berat badan dan lingkar perut oleh kader. Terus ibu diperiksa oleh bidan puskesmas di meja ke 3 tekanan darah dan cek cek kolesterol dan asam urat cuman sekarang gak ada lagi cek-cek gituan katanya alat habis terus meja terakhir ibu dikasih obat sama bidan puskesmas terus pulang”. (Informan C2)

Sedangkan pelaksanaan posbindu di masa pandemik tetap dilaksanakan dengan menerapkan protokol kesehatan yakni menjaga jarak, menggunakan masker, mencuci tangan/ handrab dan mengurangi aktivitas yang menyebabkan berkerumun (berkumpul) seperti senam. Hal ini sesuai dengan pernyataan informan petugas kesehatan pelakana posbindu yang disampaikan berikut ini:

"Tidak ada perubahan sih kayaknya mbak, tetap sama (Pelaksanaan Posbindu dimasa pandemik covid-19) yang membedakan Prokesnya lebih kita terapkan karena tidak bisa kita menunda atau kita apa mengontrol pasien pasien ptm itukan karena hal itu lebih mengerikan sebenarnya karena kalo tidak salah penelitian atau hasil apa yah dari WHO sekarang penyakitnya lebih mengarah ke PTM tingkat kematian kalo enggak salah sih begitu" (Informan A-1)

"Pernah dulu sebelum covid sering senam tapi setelah ada covid susah harus cepat-cepat gak boleh lama (Kegiatan senam). Apalagi awalawal covid itu rendah banget kunjungan karena kan orang takut terus kalo sekarang udah biasa yang jelas itu ini kalo sebelum covid kan kalo gak pakai masker juga gak papakan kalo sekarang masyarakatnya itu serba bermasker namanya andung-andung kadang sudah disuruh pakai masker nah gini kadang ajah ada giniin namanya (masker 
diturunkan ke dagu) juga andung-andung datuk datukkan tapi mereka sudah mau ke posbindu ajah udah senang" (Informan A4)

6) Pencatatan dan pelaporan

Pencatatan dan pelaporan hasil kegiatan dilakukan rutin setiap bulannya di buku rigester yang kemudian direkapitulasi untuk dilaporkan secara online (email) oleh petugas pembina posbindu ke dinas kesehatan Pesisir Barat. Hal ini sesuai dengan pernyataan informan pelaksana kesehatan posbindu sebagai berikut:

"Untuk pencatatan hasil pemeriksaan dilakukan di buku register oleh kader, kemudian petugas posbindu merekap dan melaporkan ke penanggung jawab posbindu puskesmas untuk dikumpulkan ke dinkes setiap bulannya mbak" (Informan A-1)

"Pencatatan dan pelaporan itu dilakukan oleh penanggung jawab program kemudian setiap bulannya juga dilapor ke dinas kesehatan"(Informan A-5)
7) Monitoring dan evaluasi

Evaluasi pelaksanaan kegiatan program dilakukan oleh Dinas Kesehatan Kabupaten Pesisir Barat adalah dengan melihat laporan bulanan posbindu yang dikirim oleh pihak penanggung jawab puskesmas per bulannya sedangkan monitoringnya melalui kegiatan supervisi per enam bulan sekali sehingga dapat dibahas dan ditindaklanjuti kekurangannya sedangkan monitoring serta evaluasi dari pihak puskesmas belum terlaksana. Hal ini sesuai dengan hasil wawancara informan sebagai berikut:

"Untuk kegiatan monitoring dan evaluasi lebih sering dilakukan oleh dinas mbak, kalo di puskesmas belum mbak kalo sama pihak perangkat desa kita juga belum pernah lakukan mbak" (Informan C-2)

Pihak dinas kesehatan pernah turun mbak ikut kita bulan kemarin ke posbindu" (Informan D-4)

"Kalo saat ini dari pihak puskes gak ada paling dari dinas kesehatan per enam bulan" (Informan D-5

Tabel 1. Cakupan partisipatif masyarakat di Posbindu bulan januari s/d juni tahun 2021

\begin{tabular}{llllll}
\hline Kecamatan & $\begin{array}{l}\text { Jumlah } \\
\text { penduduk }\end{array}$ & $\begin{array}{l}\text { Sasaran } \\
\text { kunjungan }\end{array}$ & $\begin{array}{l}\text { Jumlah } \\
\text { kunjungan }\end{array}$ & $\begin{array}{l}\text { Sasaran } \\
\text { kunjungan } \\
\text { hipertensi }\end{array}$ & $\begin{array}{l}\text { Jumlah } \\
\text { kunjungan } \\
\text { hipertensi }\end{array}$ \\
\hline Lemong & 12.355 & 7.783 & 900 & 2.300 & 59 \\
\hline Pesisir Tengah & 19.129 & 12.050 & 306 & 3.561 & 311 \\
\hline Pulau Pisang & 1.582 & 999 & 42 & 295 & 70 \\
\hline Krui Selatan & 9.908 & 6238 & 837 & 1.844 & 123 \\
\hline Pesisir Selatan & 20.717 & 13.060 & 1.651 & 3.860 & 215 \\
\hline KABUPATEN & 157172 & 99014 & $7317(7,39 \%)$ & 29262 & $2272(7,76 \%)$ \\
\hline
\end{tabular}

Tabel 2. Distribusi frekuensi kategori pengendalian ptm hipertensi di posbindu bulan januari s/d juni tahun 2021.

\begin{tabular}{|c|c|c|c|c|}
\hline \multirow[b]{2}{*}{ Kecamatan } & \multirow[b]{2}{*}{ Jumlah kunjungan } & \multicolumn{3}{|c|}{ Kategori } \\
\hline & & $\begin{array}{l}\text { Baik } \\
<130 / 80 \mathrm{mmHg}\end{array}$ & $\begin{array}{l}\text { Sedang } \\
130-139 / 80- \\
90 \mathrm{mmHg} \\
\end{array}$ & $\begin{array}{l}\text { Buruk } \\
>140 / 90 \mathrm{mmHg}\end{array}$ \\
\hline Lemong & 59 & 9 & 16 & 35 \\
\hline Pesisir Tengah & 311 & 53 & 82 & 176 \\
\hline Pulau Pisang & 70 & 12 & 10 & 48 \\
\hline Krui Selatan & 123 & 33 & 23 & 67 \\
\hline Pesisir Selatan & 215 & 56 & 47 & 103 \\
\hline TOTAL & 778 & 163 & 178 & 429 \\
\hline
\end{tabular}

8) Hambatan pelaksanaan kegiatan posbindu

Hambatan pelaksanaan kegiatan posbindu adalah belum terbentuknya kader, belum terjalinnya kerjasama dengan stakeholder, minimnya ketersediaan sarana dan prasarana, kondisi geografis dan rendahnya motivasi masyarakat melakukan pemeriksaan kesehatan ke Posbindu. Seperti yang dipaparkan dalam pernyataan informan petugas pelaksana kesehatan posbindu berikut ini:

"Hambatan yang dirasa menurut saya pribadi sih kurangnya alat pengecekan kolesterol, 
asam urat yang kita terssedia hanya gula darah ajah serta kita terhalang oleh laut yah jika ada ombak besar kita tidak bisa masuk kadangkala hari ini dijadwalkan ternyata tidak nyeberang karena laut jahat. Kalo hambatan internal mungkin yah kita kepada SDM sendiri yah karena SDM sendiri kita tidak bisa memaksakan sesuai kompetensinya sendiri disitu menjadi kendala. Kedua mungkin jadwal yang sering berubah-ubah sehingga petugasnya kewalahan mengatur jadwalnya. Kalo masalah eksternal mungkin berasal dari masyarakat karena masyarakat mayoritas disini nelayan jadi pas pemeriksaan ada diantara mereka yang tidak hadir karena sedang berlayar cari ikan ada. Ada yang bekerja begitu” (Informan A-5).

"Iya memang kayak gitu kita udah janjian tanggal sekian ternyata kalo lautnya jahat yah gak ada perahu itu kayak itu ajah sih, hambatan lainnya yah ketidak tersediannya alat cek stik pemeriksaan penunjang seperti kolesterolnya mbak karena memang yang dikasih dinas itu hanya beberapa gak cukup hanya dua vial. Kalo internalnya masalah dana itu kalo eksternal itu aku juga bingung masyarakat ini tidak terlalu berminat untuk usia tiga puluh lima tahun kebawah bukan tiga puluh lima tahun keatas mereka seperti masih males karena kita kan sudah kejar kan sudah digratisin semuanya tapi tetap tidak mau hadir" (Informan D-5)

Berdasarkan tabel 1. dapat ditarik kesimpulan bahwasanya jumlah kunjungan peserta Posbindu dan penderita hipertensi per kecamatan pada bulan januari s/d juni tahun 2021 masih dibawah target sasaran yang ditetapkan oleh pihak dinas kesehatan pesisir barat.

Berdasarkan tabel 2 didapatkan data bahwa hasil pemeriksaan kunjungan penderita hipertensi di posbindu selama bulan januari s/d juni tahun 2021 mayoritas peserta berada pada rentang buruk sebanyak 429 kasus sedangkan pada kategori sedang sebanyak 178 kasus dan kategori baik sebanyak 163 kasus

\section{PEMBAHASAN}

\section{Input}

\section{a) Sumberdaya}

Petugas pelaksana kegiatan Posbindu adalah kader yang memiliki kriteria mampu membaca dan menulis, memiliki motivasi serta mampu menjalankan tugas serta memiliki sertifikat yang menerangkan telah dilatih minimal oleh Puskesmas pembinanya serta berjumlah lima orang yang memiliki peran sebagai kader koordinator, kader pergerak, kader pemantauan, kader konselor edukator dan kader pencatat [12]. Pelaksanaan posbindu dilakukan oleh kader dengan dibantu tenaga kesehatan Puskesmas. Hal ini dikarenakan kader belum memenuhi standar panduan penyelenggaraan posbindu yakni jumlah kader kurang dari lima orang serta belum memiliki sertifikat pelatihan posbindu hal ini dikarenakan keterbatasan pendanaan, ketidakmauan masyarakat menjadi kader, kurangnya dukungan pemangku kebijakan setempat yakni kepala camat, kepala desa, tokoh adat dan sebagainya. Hal ini selaras dengan penelitian yang dilakukan Primiyani et al., yang menyatakan pelaksanaan Posbindu di wilayah Kota Solok belum optimal dikarenakan minimnya SDM, keterbatasan anggaran serta belum terjalinnya lintas sektor [13]. Berdasarkan hasil penelitian mayoritas petugas posbindu belum mendapatkan pelatihan dan pembinaan dari Puskesmas. Hal ini dikarenakan pelatihan terhadap kader hanya dilakukan oleh pihak dinas kesehatan sedangkan pihak puskesmas belum memiliki inisiatif untuk melakukan pelatihan dan pembinaan kader secara mandiri diwilayah kerjanya dikarenakan belum terlatihnya tenaga kesehatan puskesmas. Puskesmas berperan penting dalam keberlangsungan pelaksanaan Posbindu.

Salah satu peran puskesmas adalah membimbing para kader dalam menyelenggarakan kegiatan Posbindu sehingga para kader terlatih melakukan deteksi dini penyakit, pengukuran tinggi badan, menimbang berat badan, pengukuran tekanan darah, pemeriksaan laboratorium sederhana (kolesterol dan kadar gula darah), konseling serta penyuluhan kepada peserta Posbindu. Penelitian ini didukung dengan penelitian Suhbah et al.,menyatakan SDM bertugas dalam pelaksanaan Posbindu belum memiliki kompetensi yang cukup, sertifikat maupun Surat keterangan tugas (SK) posbindu PTM [14]. Dalam menjamin keberlangsungan pelaksanaan Posbindu yang baik dan optimal haruslah dilakukan oleh kader yang terlatih minimal surat keterangan dari Puskesmas pembinanya [12].

\section{b) Sarana prasarana}

Keberlangsungan pelaksanaan kegiatan posbindu PTM ditentukan oleh ketersediannya sarana dan prasarana dalam pengukuran dan pemeriksaan sehingga tujuan yang diharapkan dapat tercapai. Pelaksanaan kegiatan Posbindu diselenggarakan di balai pekon (balai desa) 
disetiap kecamatan. Dalam rangka menunjang pelayanan posbindu, setiap puskesmas sudah memiliki satu set posbindu kit yang bersumber dari dinas kesehatan tetapi pelaksanaan posbindu belum maksimal dikarenakan jumlah posbindu kit yang tersedia masih kurang. Hal ini dikarenakan jumlah posbindu per kecamatan berbeda-beda, adanya keterbatasan bahan habis pakai seperti stick pemeriksaan, lamanya jadwal kalibrasi alat dan pergantian alat rusak dari pihak dinas kesehatan sehingga capaian cakupan program Posbindu belum sesuai dengan yang diharapkan. Untuk memenuhi kekurangan bahan habis pakai seperti stick pemeriksaan pihak puskesmas terlebih dahulu melakukan konfirmasi ketersediaan kepada pihak dinas kesehatan jika ternyata bahan tidak tersedia maka pihak puskesmas mengusahakan melalui permintaan bantuan bahan habis pakai kepada peratin desa (kepala desa) dan memanfaatkan dana puskesmas (BOK) serta meminimalisir penggunaan alat pemeriksaan (stick) dengan melakukan pemeriksaan hanya kepada peserta yang memiliki riwayat penyakit dan keluhan yang membutuhkan pemeriksaan kolesterol, kadar gula darah dan asam urat.

Minimnya sarana dan prasarana juga menjadi penyebab masyarakat kurang antusias untuk memeriksakan diri ke Posbindu PTM. Penelitian ini sejalan dengan Annisa mengatakan Puskesmas Polonia belum memiliki sarana dan prasarana yang lengkap yang berakibat pada kurang maksimalnya pelayanan [10]. Penelitian ini juga didukung oleh pernyataan Frieden dalam Nugraheni et al., yakni ketercapaian program masyarakat dipengaruhi oleh ketercukupannya sarana prasarana guna meningkatkan kinerja petugas [15]. Menurut Suhbah menyatakan Puskesmas Sukolilo I Kabupaten Pasti memiliki keterbatasan sarana dan prasarana Posbindu PTM [14]. Oleh karena itu, dukungan sarana serta prasarana yang cukup menjadi salah satu aspek yang diperlukan dalam keberhasilan pelaksanaan Posbindu PTM.

\section{c) Pendanaan}

Pendanaan pelaksanaan kegiatan program posbindu bersumber dari iuran masyarakat, dana Bantuan Operasional Posbindu (BOK) Puskesmas, instansi-instansi swasta maupun setempat, LSM dan sebagainya sehingga kegiatan Posbindu dapat berkelanjutan. Berdasarkan hasil penelitian sumber pendanaan kegiatan Posbindu bersumber dari BOK
(Bantuan Operasional Kesehatan) dan JKN (Jaminan Kesehatan Nasional) sementara dana desa hanya beberapa desa yang menganggarkan dananya untuk kegiatan Posbindu. Hal ini selaras dengan penelitian oleh Yanti menyatakan bahwa kegiatan dapat berjalan dengan baik jika adanya pembiayaan yang cukup dengan bersumber dari dana mandiri ataupun dukungan dari wilayah setempat [16].

\section{d) Partisipatif masyarakat}

Kegiatan Posbindu adalah kegiatan yang bersumber dari masyarakat, oleh masyarakat dan untuk masyarakat sehingga partisipatif masyarakat untuk melakukan pemeriksaan kesehatan di Posbindu sangatlah berpengaruh dalam keberlangsungan pelaksanaan Posbindu sehingga masyarakat yang sehat tetap sehat, masyarakat yang memiliki faktor-faktor risiko dicegah agar tidak menjadi penyakit tidak menular sedangkan penyandang ptm dikendalikan agar mengurangi kesakitan, kecacatan dan kematian dikarenakan penyakit tidak menular. Berdasarkan hasil penelitian didapatkan data respon masyarakat belumlah baik dikarenakan peserta yang hadir mayoritas para usia tua dibandingkan usia muda. Secara sistematic review asha et al menyatakan pada negara-negara maju partisipatif masyarakatnya terhadap pelaksanaan program kesehatan berupa preventif mencapai tujuh puluh delapan (78\%) sedangkan pada negara berkembang jauh lebih rentan terjadi penolakan dari masyarakatnya terkait pemberian edukasi pendidikan kesehatan dan hal ini masih menjadi hambatan bagi negara Indonesia. Pelaksanaan Posbindu diperuntukan kepada masyarakat yang berusia diatas 15 tahun dengan sasaran pemeriksaan gula darah, kolesterol adalah setiap warga negara berusia $>40$ tahun atau $<40$ tahun yang memiliki faktor resiko obesitas atau hipertensi [17].

Faktor penyebab rendahnya partisipatif masyarakat ke posbindu di Kabupaten Pesisir Barat dikarenakan rendahnya pengetahuan tentang pentingnya posbindu, jadwal pelaksanaan posbindu yang bersamaan dengan kegiatan lain seperti pekerjaan, sedang sekolah, pesta sedang diluar wilayah dll, keterbatasan sarana prasarana seperti pengecekan (kolesterol, kadar dula darah dan asam urat), akses menuju ke posbindu, jumlah kader belum memenuhi standar, belum dilatihnya petugas posbindu, kurang menariknya posbindu dikarenakan kegiatan yang monoton dan belum 
terjalinnya lintas sektor dengan perangkat desa. keluarga dan belum tersedianya inovasi untuk menarik minat masyarakat ke posbindu. Meningkatkan minat masyarakat untuk aktif mengunjungi posbindu juga dapat dilakukan melalui sosialisasi program PTM melalui penyebararan informasi berbasis website, media-media sosial, spanduk atau leaflet atau kontak langsung dengan masyarakat via nomor telepon atau email serta membuat kegiatankegiatan yang mampu menarik perhatian masyarakat berbagai kelompok usia seperti kegiatan pengobatan secara gratis, bersepeda santai, pemberian hadiah doorprize kepada peserta aktif dan sebagainya serta peningkatan kerjasama lintas sektor [15].

\section{Proses}

Pelaksanaan Posbindu dimulai dari kegiatan perencanaan meliputi jadwal pelaksanaan kegiatan yang telah disusun disampaikan kepada kader agar kader mempersiapkan lokasi kegiatan serta peralatan dan menyebarkan pengumuman terakait waktu pelaksanaan posbindu. Pelaksanaan posbindu dilaksanakan setiap bulannya dan bertempat di balai pekon (desa). Pelaksanaan Posbindu dimulai dari kegiatan pemberian informasi dari penanggung jawab posbindu puskesmas kepada kader Selanjutnya kader memberitahukan pelaksanaan posbindu dengan memanfaatkan sarana ibadah satu hari sebelum hari pelaksanaan namun ada juga dua sampai tiga hari menjelang pelaksanaan kegiatan posbindu. Dalam pelaksanaannya kegiatan posbindu terintegrasi dengan kegiatan posyandu lansia, puskesmas keliling dan kesehatan jiwa. Hal ini dikarenakan petugas kesulitan dalam mengumpulkan masyarakat jika kegiatan posbindu dilaksanakan secara terpisah. Pelaksanaan Posbindu belum menerapkan 5 tahapan dikarenakan keterbatasan ruangan, keterbatasan jumlah petugas posbindu, keterbatasan sarana prasarana dan adanya kegiatan pengobatan dan screeaning jiwa.

Alur pelayanan kegiatan Posbindu meliputi meja 1 adalah pendaftaran; meja dua adalah pengukuran tinggi badan, menimbang dan lingkar perut; meja ketiga adalah pengukuran tekanan darah, pemeriksaan laboratorium sederhana; meja ke empat adalah pengobatan, konseling dan perujukan namun jika kegiatan terintegrasi dengan program jiwa dan pusling maka kegiatan pengobatan, konseling dan rujukan berada pada meja ke lima. Hal ini menunjukan bahwa pelaksanaan posbindu belum sesuai dengan standar operasional prosedur (SOP) yang diterbitkan kemenkes yaitu tidak dilaksanakannya kegiatan wawancara faktor risiko PTM dan hasil wawancara informan ini didukung dengan hasil observasi kelengkapan dokumentasi laporan posbindu menunjukan format laporan hanya bertuliskan nomor peserta, identitas (Nama, umur, Alamat), hasil pemeriksaan (tinggi badan, berat badan, lingkar perut,tekanan darah, kadar gula darah, asam urat), diagnosa dan Nomor JKN. Sedangkan format yang berstandar sesuai dengan juknis pelaksanaan posbindu meliputi Nomor, identitas (Nama, umur, nomor kependudukan, nomor JKN, Golongan darah, Status menikah dan pekerjaan ), kunjungan lama atau baru, hasil wawancara faktor risiko meliputi: kurang konsumi sayur buah, merokok, kurang aktifitas, riwayat penyakit keluarga, riwayat penyakit dahulu, hasil pemeriksaan seperti tekanan darah, berat badan, tinggi badan, IMT, Lingkar perut, kadar gula darah, kolesterol).

Pelaksanaan Posbindu dimasa pandemic covid-19 sudah sesuai dengan buku pedoman adaptasi kebiasaan baru dalam pencegahan dan pengendalian ptm namun masih rendahnya motivasi peserta untuk tetap menggunakan masker selama proses kegiatan posbindu dikarenakan ketidaknyamanan dan kesulitan bernafas. Tujuan akhir dari kegiatan posbindu adalah faktor risiko penyakit tidak menular dapat dicegah dan dikendalikan lebih dini sehingga faktor risiko yang telah terpantau secara rutin dapat selalu terjaga dengan rutin pada kondisi normal atau tidak berada pada kategori buruk. Pelaksanaan rujukan diwilayah kerja Kabupaten Pesisir Barat sudah melakukan perujukan kepada peseta Posbindu dengan indikasi 1 pengukuran dan pemeriksaan kadar gula darah, kolesterol, asam urat dan tekanan darah tidak terkendali serta sudah mengalami komplikasi sedangkan dengan hasil pemeriksaan normal dilakukan konseling atau edukasi tentang diet yang sehat, aktifitas yang cukup serta gaya hidup sehat tetapi tidak dilakukan pendokumentasian didalam buku register.

Peserta Posbindu belum memiliki KMS (Kartu Menuju Sehat) faktor risiko PTM sehingga pencatatan hanya dilakukan di buku register posbindu. Pencatatan hasil kegiatan Posbindu PTM umumnya dilakukan oleh kader sedangkan petugas puskesmas mengambil data 
hasil kegiatan posbindu PTM dalam bentuk laporan rutin bulanan yang diteruskan ke dinas kesehatan pesisir barat sedangkan supervisi dan pertemuan dari dinas kesehatan rutin dilakukan per enam bulan sekali sehingga kegiatan monitoring dan evaluasi berjalan dengan baik namun pertemuan dan supervisi bulanan sebagai umpan balik pelaksanaan program belum terlaksana di puskesmas. Monitoring diharapkan dapat dilakukan sebulan sekali di lokmin bulanan atau lokmin triwulan sebagai bahan penilaian kegiatan yang telah lalu, sebagai informasi besaran faktor risiko PTM di wiilayah kerja puskesmas serta menilai tingkat kinerja pelaksanaan kegiatan Posbindu PTM, serta membuat dan menyusun perencanaan terkait pengendalian Penyakit Tidak Menular untuk tahun berikutnya.

\section{Output}

Pelaksanaan posbindu terkait waktu sudah sesuai sedangkan terkait tujuan posbindu belum sesuai hal ini terlihat dari rendahnya cakupan kunjungan masyarakat yang memeriksakan diri ke Posbindu dari januari s/d juni sebesar 7,39\% atau sekitar 7317 kunjungan dari 99014 kunjungan sasaran. Data ini tentunya juga memberikan informasi bahwa capaian belum sesuai dengan target yang ditetapkan dalam juknis kementerian kesehatan yakni diatas 50\%. Dalam hal pelaksanaan kegiatan posbindu belum sesuai dengan Standar Operasional Prosedur (SOP) yang ditetapkan dalam juknis penyelenggaraan Posbindu yakni penerapan 5 tahapan meja dan wawancara faktor risiko PTM tidak dilaksanakan sehingga peserta posbindu yang memiliki faktor resiko PTM tidak terscreening dengan baik sehingga berpotensial terdiagnosa $\mathrm{ptm}$ sedangkan penyandang PTM beresiko kecacatan bahkan kematian. Alur pelaksanaan Pelaporan kegiatan pelaksanaan Posbindu di Kabupaten Pesisir Barat adalah dari kader kemudian direkapitulasi oleh penanggung jawab kegiatan posbindu yang kemudian diteruskan ke dinas kesehatan melalaui email. Namun laporan terkait jumlah rujukan dari posbindu ke puskesmas belum tercatat dalam laporan pada bulan januari s/d juni tahun 2021 tetapi kegiatan perujukan yang dilaksanakan di Posbindu Kabupaten Pesisir Barat telah sesuai dengan petunjuk penyelenggaraan Posbindu.

Hipertensi merupakan jenis penyakit tidak menular dengan jumlah kasus terbanyak di Posbindu Kabupaten Pesisir Barat. Capaian kunjungan hipertensi di Kabupaten Pesisir
Barat terhitung bulan januari s/d juni tahun 2021 masih dibawah target sasaran $10 \%$ yakni $7,76 \%$ atau setara dengan 2272 kunjungan dari target sasaran yakni 29262 kunjungan. Data hasil pemeriksaan tekanan darah penderita hipertensi yang berkunjung ke Posbindu pada bulan januari s/d juni tahun 2021 menunjukkan mayoritas peserta hipertensi berada pada rentang kategori buruk sebanyak 429 kasus sedangkan pada kategori sedang sebanyak 178 kasus dan kategori baik sebanyak 163 kasus. Data ini menunjukan bahwa pengendalian terhadap faktor resiko pada penyandang Penyakit Tidak Menular dengan jenis penyakit hipertensi belum optimal yang berdampak pada tidak terkendalinya kasus hipertensi di Kabupaten Pesisir Barat.

\section{KESIMPULAN DAN SARAN}

Pelaksanaan kegiatan Posbindu belum efektiv dibuktikan melalui ditemukannya kendala dalam input: ketidakcukupan sumberdaya, ketidaklengkapan dan ketidakcukupan sarana prasarana, ketidakcukupan pendanaan; kendala dalam proses: pelaksanan kegiatan belum sesuai SOP, belum terdistribusinya buku pintar kader, rendahnya sosialisasi dan penyuluhan $\mathrm{ptm}$ di posbindu dan aparatur desa, ketidaktersediaan Kartu Menuju Sehat (KMS) bagi peserta posbindu, ketidaklengkapan laporan, rendahnya stakeholder; kendala output: ketidaksesuaian sasaran, cakupan kunjungan rendah, rendahnya pendokumentasian pencatatan dan rujukan berdampak pada ketidakterkendalian PTM yakni hipertensi.

\section{DAFTAR PUSTAKA}

[1] Kementerian Kesehatan RI. 2020. Panduan Adaptasi Kebiasaan Baru dalam Pencegahan dan Pengendalian Penyakit Tidak Menular. Kementerian Kesehata RI, Jakarta.

[2] Peraturan Menteri Kesehatan Republik Indonesia No. 71. 2015. Penanggulangan Penyakit Tidak Menular. 2015. Berita Negara Republik Indonesia, Jakarta.

[3] Badan Penelitian dan Pengembangan Kesehatan Kementerian RI. 2013. Riset Kesehatan Dasar (Riskesdas) tahun 2013. Kementerian Kesehatan RI, Jakarta.

[4] Badan Penelitian dan Pengembangan Kesehatan Kementerian RI. 2018. Riset Kesehatan Dasar (Riskesdas) tahun 2018. Kementerian Kesehatan RI, Jakarta. 
[5] Peraturan Menteri Kesehatan Republik Indonesia No. 5. 2017. Rencana Aksi Nasional Penanggulangan Penyakit Tidak Menular Tahun 2015-2019. Menteri Kesehatan Republik Indonesia, Jakarta.

[6] Kementerian Kesehatan Republik Indonesia. 2020. Profil Kesehatan Indonesia Tahun 2019. Kementerian Kesehatan RI, Jakarta.

[7] Kementerian Kesehatan RI. 2019. Data Dasar Puskesmas Provinsi Lampung kondisi 31 Desember 2018. Kementerian Kesehatan Republik Indonesia, Jakarta.

[8] BPS-Statistics of Lampung Barat Regency. 2019. Kabupaten Pesisir Barat Dalam Angka 2019. Badan Pusat Statistik Kebupateng Lampung Barat, Pesisir Barat.

[9] Mahdur, R. R., \& Sulistiadi, W. 2020. Evaluasi Program Pos Pembinaan Terpadu Penyakit Tidak Menular ( Posbindu PTM ). Jurnal Ilmiah Kesehatan Masyarakat, 12, 43-49.

[10] Annisa, N. 2016. Analisis Pelaksanaan Program Pos Pembinaan Terpadu Penyakit Tidak Menular Diwilayah Kerja Puskesmas Kecamatan Medan Polonia Tahun 2016. Jurnal Kesehatan Masyarakat. Jurusan Ilmu Kesehatan Masyarakat Universitas Sumatera Utara Medan (2016) 1(2) 6-38.

[11] Damayanti, Fanny (2016). Analisis Pelakssanaan Program Pos Pembinaan Terpadu Penyakit Tidak Menular (Posbindu PTM) di Puskesmas Glugur Darat. Skripsi. Fakultas Kesehatan Masyarakat. Universitas Sumatera Utara. Medan.

[12] Direktorat Jenderal Pencegahan dan Pengendalian Penyakit. (2019). Petunjuk Teknis Pos Pembinaan Terpadu Posbindu Bagi Kader. Direktorat Pencegahan dan Pengendalian Penyakit Tidak Menular, Jakarta

[13] Primiyani, Y., Masrul, M., \& Hardisman, H. (2019). Analisis Pelaksanaan Program Pos Pembinaan Terpadu Penyakit Tidak Menular di Kota Solok. Jurnal Kesehatan Andalas, $\quad 8(2), \quad 399 . \quad$ Dari: https://doi.org/10.25077/jka.v8.i2.p399406.2019 Diakses 15 juli 2021

[14] Suhbah, W. D. A., Suryawati, C., \& Kusumastuti, W. (2019). Evaluation of the implementation of the integrated noncommunicable disease (Posbindu PTM) Puskesmas Sukolilo I, Pati District. Jurnal Kesehatan Masyarakat, 7(4), 647-657.

[15] Nugraheni, W. P., Hartono, R. K., Humaniora, P., Kesehatan, M., Penelitian, B., Kesehatan, P., Tinggi, S., Kesehatan, I., \& Maju, I. 2018. Strategies of Posbindu
Program for Noncommunicable Diseases in Bogor City. Jurnal Ilmu Kesehatan Masyarakat, 9(3), 198-206. Dari: https://doi.org/10.26553/jikm.2018.9.3.

Diakses 24 juli 2021

[16] Yanti NE, Lubis NL, Diana VE .2019. Analisis Implementasi Kebijakan Puskesmas Dalam Program Pos Pembinaan Terpadu Penyakit Tidak Menular. MPPKI. 2019 [cited 2021 Juni 18];2(3). Dari: https://doi.org/10.31934/mppki.v2i3.

Diakses 20 Juli 2021

[17] Direktorat Jenderal Pencegahan dan Pengendalian Penyakit . (2020). Rencana Aksi Kerja Kegiatan Direktorat P2PTM. Direktorat Pencegahan dan Pengendalian Penyakit Tidak Menular. Jakarta. 